\title{
Taliban and Jihadist Terrorist Use of Strategic Communication
}

\author{
Carsten Bockstette
}

\section{Introduction}

For Taliban and Jihadist terrorists, strategic communication is a vital part of their asymmetrical war fighting campaign. ${ }^{1}$ As long as the Eastern Bloc existed, military conflicts were largely determined by the policy of the United States and the Soviet Union, and were therefore part of the larger East-West conflict. Since this symmetricalglobal conflict was decided in favor of the West, numerous asymmetrical conflicts have erupted around the globe. Terrorist actions, like the attack in Mumbai, India in November 2008, have become a worldwide menace. In particular, Islamic jihadist terrorism has spread beyond the borders of the regions in which it originated and has taken on a global dimension. The terrorist use of airliners as massive flying bombs in the attacks on New York and Washington on 11 September 2001 was a sad climax in this new dimension of asymmetrical conflicts. To offset this threat requires knowledge of what motivates, feeds, and sanctions jihadist terrorists and their followers. Research and analysis of the root causes and underlying conditions, motivators, and enablers of terrorism - including the propaganda strategies of terrorists - are vital to shaping appropriate countermeasures to the threat from Islamist terrorism. The complex set of interactions and dependencies between media and terrorism still need to be investigated more fully. In particular, further research is needed into the ways that terrorists utilize the Internet. One way to begin this investigation - and the approach this paper takes - is to study the communication techniques that jihadists use according to the elements that are used to generate a strategic communication management plan.

The theoretical terrorist communication plan described in this essay shows that jihadist terrorists know how to apply strategic communication management techniques in disseminating their messages. The mass media, and especially the Internet, have become the key enablers and the main strategic communication assets for terrorists and have ensured them a favorable communication asymmetry. With these assets, terrorists

\footnotetext{
Major Dr. Carsten Bockstette is currently the Operations and German Liaison Officer in the Strategy, Plans and Analysis Group at the George C. Marshall European Center for Security Studies in Garmisch-Partenkirchen, Germany. He holds a doctorate in political science from the Helmut Schmidt University in Hamburg.

1 Jihad is a religious duty of Muslims. In Arabic, the word jihād is a noun meaning "struggle." Persons engaged in jihad are called mujahideen. In this paper, the term "jihadist terrorists" describes (Al Qaeda networked) Islamist terrorists that draw on extreme interpretations of Islam for their rationale, their ideology, and their motivation. Their focus is not limited to any one national or ethnic milieu. The Taliban are limited to a regional milieu (Afghanistan and Pakistan), but they also draw on extreme interpretations of Islam similar to those used by Jihadist terrorists.
} 
are able to compensate for a significant part of their unfavorable asymmetry in military power. Jihadist terrorists place a great deal of emphasis on developing comprehensive communication strategies in order to reach their desired short-, mid-, and long-term goals and desired end states. Their ability to develop and implement such sophisticated strategies shows both their fanatic conviction and their professionalism. They craft their strategies based on careful audience analysis and adapt their messages and delivery methods accordingly, adhering to the fundamental rules underlying any communication or public relations campaign. Their skillful use of the mass media and the Internet to compensate for asymmetrical disadvantages has enabled them to keep generating new generations of jihadist terrorists.

This information asymmetry must be undermined if the global community is to counter the appeal that the jihadist movement holds in Muslim communities around the world. To successfully employ a strategic counter-communication plan, it has to be an integral part of a comprehensive approach of coercive military and law enforcement measures and conciliatory political, diplomatic, and socio-economic measures.

\section{Key Terminology}

There is no generally accepted academic definition of terrorism or asymmetrical conflict. A look at the history of war shows that the genuinely symmetrical war-a war between equal opponents - is the exception, whereas asymmetrical wars and conflicts seem to be the norm. One could argue that in all wars the conflict is about the creation of unequal, asymmetrical relations in favor of one's own side in order to win the campaign. If one speaks about the art of war, one has to consider the following battle space dimensionsknowledge, strength, time, and space-all in conjunction with ingenuity. Knowledge stands for high-quality, mission-relevant information that is readily available to one's own side but is kept from one's opponents, in order to guarantee qualitative intelligence superiority. Strength stands for quantity and quality of force, in every dimension. Time refers to speed, endurance, timeliness, diligence, or a combination thereof. Space describes area, depth, scope of action, and society. Ingenuity conveys the astuteness of a cadre's leadership qualities, the use of unconventional actions, and/or the refusal to follow conventions. The art behind great military leadership is the art of creating and applying asymmetry in all five dimensions. As Carl von Clausewitz put it, "the seeds of wisdom that are to bear fruit in the intellect are sown less by critical studies and learned monographs than by insights, broad impressions, and flashes of intuition."2

In conflicts and wars between states, one speaks of symmetrical conflicts, in spite of existing or aimed-for asymmetries. Likewise, intra-state conflicts are not considered to be asymmetrical conflicts, since they have a substantially smaller asymmetric dimension. ${ }^{3}$

\footnotetext{
Carl von Clausewitz, Vom Kriege (On War) (Troisdorf: Bildungsverlag Eins, 2003), 22.

3 Ernst König, "Österreich - ein Beispiel? (Austria - an Example?)," in Asymmetrische Kriegführung - ein neues Phänomen der Internationalen Politik (Asymmetric Warfare, a New Phenomenon of International Policy), ed. Josef Schröfl and Thomas Pankratz (Baden-Baden: Nomos, 2004), 133-44.
} 


\section{Asymmetrical Conflicts}

Asymmetrical conflicts are conflicts between parties that show essential quantitative and/or qualitative dissimilarities in key battle space dimensions: an imbalance in forces, a different determination/motivation, a different legitimization, a different application of methods, and a difference in the quality or character of the military methods themselves. Asymmetrical conflicts are usually waged in a changing, asynchronous, and unpredictable manner. The general tendency of asymmetrical approaches is to strike the opponent at one or several conflict-determining centers in order to achieve one's (usually limited and specific) goals. A new dimension of asymmetrical conflict stems from the use of the mass media, especially the Word Wide Web, to spread information; the worldwide repercussions of such conflicts; and the increased threat of the use of weapons of mass destruction by terrorists. ${ }^{4}$

\section{Terrorism}

The discipline of terrorism research is relatively young, and thus has no generally accepted academic definition for terrorism. The word terror comes from the Latin word terrere, which means to frighten or scare. The concept of terrorism goes back to the nineteenth century, but terrorism as a politico-military strategy has existed for about forty years. The recent fusion of terrorist messages with the global mass media has allowed terrorism to take on a worldwide dimension. In this paper, terrorism is defined as political violence in an asymmetrical conflict that is designed to induce terror and psychic fear (sometimes indiscriminate) through the violent victimization and destruction of noncombatant targets or iconic symbols. Such acts are meant to send a message to a local, national, or global community from an illicit, clandestine organization. The purpose of terrorism is to exploit the media in order to achieve maximum attainable publicity as a force multiplier in order to influence the targeted audience(s) in pursuit of short- and mid-term political goals and/or desired long-term end states.

Terrorists do not primarily aim at producing maximum physical damage with their attacks, but rather strive for the greatest possible psychological effect. Terrorism uses a strategy that primarily relies on the symbolic strength of the act. Thus terror does not primarily serve the purposes of fighting, injuring, or destroying the opponent; rather, its primary purpose lies in the conveying of messages to the target audience(s). Terrorists perpetrate their acts without regard for the conventions of warfare. The symbolism originating from terrorist acts and the media marketing thereof is intended to address the public, to use them as a vehicle and a communication channel to influence the

4 See Herfried Münkler, Der Wandel des Krieges: Von der Symmetrie zur Asymmetrie (The Change of War: From Symmetry to Asymmetry) (Weilerswist: Velbrück, 2006); and Georg Geyer, "Zündschnur der Asymmetrie: Grundsätzliche Überlegungen zum Verhältnis von Politik, Massenkommunikation und Gesellschaft in asymmetrischen Konflikten (Fuse of the Asymmetry: Basic Considerations to the Relation of Politics, Mass Communication and Society During Asymmetrical Conflicts)," in Asymmetrische Kriegführung - ein neues Phänomen der Internationalen Politik (Asymmetric Warfare, a New Phenomenon of International Policy), ed. Schröfl and Pankratz (Baden-Baden: Nomos, 2004), 283-98. 
political representatives/decision makers and other target audiences. Terrorists fight with limited resources from the underground against adversaries that they would be unable to defeat by military means. Terrorist groups often proclaim themselves to be guerrillas, or to have to lead partisan campaigns with unconventional fighting methods to compensate for their military inferiority. Unlike some kinds of partisans, terrorists are not capable of winning a direct military confrontation, and therefore avoid it. ${ }^{5}$ Terrorists are generally driven to commit acts of terrorism to express and redress their grievances and demands due to a variety of factors, which can be either rational or irrational. These root causes usually consist of multiple static or dynamic combinations of factors and circumstances, ranging from general to specific conditions, motivators, and enablers, some of which may be more important than others. They can be global, regional, or local in origin, and societal, structural, or psychological in nature.

\section{Strategic Communication Management}

For the purposes of this paper, strategic communication management is defined as the systematic planning and realization of information flow, communication, media development, and image care with a long-term horizon. It conveys deliberate messages through the most suitable media to designated audiences at the appropriate time to contribute to and achieve the desired long-term effect. Communication management is process creation, and has to bring three factors into balance: the messages, the media channels, and the audiences. ${ }^{6}$

Research gaps still exist concerning the media effects of terrorism and the ways that terrorist groups employ mass media. In particular, the utilization of the Internet by terrorists needs further research. As mentioned above, this essay will use the framework of strategic communication management (outlined below in Figure 1) to examine the ways in which jihadist terrorist groups communicate with the outside worlds about their grievances, methods, and goals.

\section{The Desired End State of Jihad}

Jihadist terrorism is ostensibly motivated by an extreme interpretation of Islam. Its practitioners regard the use of violence as a divine duty or sacramental act. ${ }^{7}$ The jiha-

5 Carsten Bockstette, "Terrorismus und asymmetrische Kriegsführung als kommunikative Herausforderung (Terrorism and Asymmetric War Fighting as a Communicative Challenge)," in Strategisches Informations- und Kommunikationsmanagement. Handbuch der sicherheitspolitischen Kommunikation und Medienarbeit (Strategic Information- and Communication Management. Manual for the Military Communication and Media Work), ed. Carsten Bockstette, Walter Jertz, and Siegfried Quandt (Bonn: Bernard \& Graefe Verlag, 2006).

See Strategisches Informations- und Kommunikationsmanagement. Handbuch der sicherheitspolitischen Kommunikation und Medienarbeit (Strategic Information- and Communication Management. Manual for the Military Communication and Media Work.

7 Europol, EU Terrorism Situation and Trend Report, 2007; www.europol.europa.eu/ publications/EU_Terrorism_Situation_and_Trend_Report_TE-SAT/ TESAT2007.pdf. 


\section{Figure 1: Strategic Communication Management Planning Process}

(Simplified Model)

1. Analyze and develop the final desired end states and establish your communication goals:

- Reputation

- Image

- Brand name

- Deliberate message

- Desired action

2. Analyze your communication infrastructure:

- Suitable media

- Timing

- Personal, technical, and financial capacities

3. Target your audience(s) and select communication channels:

- General public

- Own patronage

- Multipliers within society

- Journalists

- Decision makers

- Call to audience to do something specific

- Convey your deliberate messages utilizing appropriate media

4. Develop and execute the strategic communication management plan:

- Define communication objectives

- Develop communication tactics

- Establish strategies

- Write strategic communication management plan

- Execute strategic communication plan and associated tasks

5. Track and evaluate

- Feedback

- Media analysis

- Monitoring of audience actions

- Comparison of desired end states and defined goals 
dist terrorists' self-proclaimed goal is to reinvigorate the Islamic $U m m a h^{8}$ and to mobilize the Muslim community in a revolutionary transformation of the Muslim world population in confrontation with the international order embodied by Western society. They strive toward the creation of a new global Islamic caliphate (or, in the case of the Taliban, a local national caliphate), which Islamist terrorists widely consider the ideal Islamic form of government representing the political unity and leadership of the Muslim world. In a 2006 interview, the Al Qaeda ideologue Abu Musab-al Zarqawi explained the jihadists' goal thus:

Our political agenda ... is that of the saying of the Prophet (peace be upon him), I have been sent with the sword, between the hands of the hour, until Allah is worshipped alone ... this is what determines our political goal. We fight in the way of Allah, until the law of Allah is implemented, and the first step is to expel the enemy, then establish the Islamic state, then we set forth to conquer the lands of Muslims to return them back to us, then after that, we fight the kuffar (disbelievers) until they accept one of the three. I have been sent with the sword, between the hands of the hour; this is our political agenda. ${ }^{9}$

Rooted in Pashtu tribal areas, the Taliban — who are currently trying to gain/regain political power in the region-are primarily focused on Afghanistan and Pakistan.

\section{Short-term Goals}

In the short term, the jihadist terrorists' aim is to enlarge the scope of their supportive patronage. Therefore, the persuasion of receptive global Muslim audiences via the heightening of an Islamic identity in confrontation with the West is one of their goals. This includes engaging (and enraging) the Muslim population by luring the U.S. into conflicts in order to be able to engage the enemy directly. Again, the Taliban share these goals on a regional scale. The terrorists need Western troops and their military action in the Muslim world in order to implement their media strategy. The presence of troops and their actions produce the desired graphic footage of Western "occupation of Islamic nations" that furthers their media-centered strategy. It thrives on images and words about every innocent civilian killed by Western bombs transmitted via television and the Internet, producing intense antipathy towards the West. Building on this, the terrorists can more effectively call for the end of foreign influence in Muslim countries. Therefore, even though it is an obvious contradiction, another of their stated short-term goals is to drive those they call invaders from Muslim nations. ${ }^{10}$ The most promising

8 The Ummah, or community of believers, is revered because it is seen as the successor to Muhammad's political authority. The caliphate, as the only form of governance that has full approval in traditional Islamic theology, is the core political concept that jihadist terrorists strive to realize.

9 “Zarqawi Interview Part Two: Dialogue with Sheikh Abu Musab Al-Zarqawi," Jihad Unspun (11 January 2007); available at http://www.jihadunspun.com/intheatre_internal.php?article $=106976 \&$ list $=$ /home.php.

10 Angela Gendron, "Trends in Terrorism Series: Al-Qaeda: Propaganda and Media Strategy," ITAC Presents 2 (2007); available at www.csis-scrs.gc.ca/en/itac/itacdocs/2007-2.asp. 
approach to achieve this end is to attack allies of the U.S.-led coalition that are judged the most vulnerable (those with weak governments or poor public support for involvement), in order to induce their governments to pull out their troops. The underlying strategy is to isolate the United States by dividing and undermining its coalition, thereby indirectly forcing the U.S. and its coalition to withdraw. Therefore, the terrorists carry out a combination of attacks against U.S. forces and coalition forces. The Norwegian Defense Research Establishment provides evidence of this, quoting from the Media Committee for the Victory of the Iraqi People, a lengthy Al Qaeda planning document found on a radical Islamist Web site in December 2003: "We think that the Spanish government could not tolerate more than two, maximum three blows, after which it will have to withdraw because of popular pressure. If its troops still remain in Iraq after those blows, then the victory of the Socialist Party is almost secured, and the withdrawal of the Spanish forces will be on its electoral program."11

\section{Intermediate and Long-term Goals}

In the mid-term, the jihadist terrorists' goals include the removal of all political leaders who currently govern secular Muslim states and the elimination of the state of Israel. The terrorists' aim is to install supportive Islamic regimes and transform the current fractious political landscape of the Muslim world from a decentralized network organization to a massive Islamic movement that strives toward their desired end state. In a 2007 article titled "Pakistan: The Taliban Takeover," Ziuddin Sardar wrote:

Pakistan is reverberating with the call of jihad. Taliban-style militias are spreading rapidly out from provinces in the far north-west. The danger to the country and to the rest of the world is escalating. ... The new generation of militants are all Pakistani; they emerged after the US invasion of Afghanistan and represent a revolt against the government's support for the US. ... They are led by young mullahs who, unlike the original Taliban, are technology- and media-savvy, and are also influenced by various indigenous tribal nationalisms, honouring the tribal codes that govern social life in Pakistan's rural areas. ... The Taliban have declared Waziristan an "Islamic emirate" and are trying to establish a parallel administration, complete with sharia courts and tax system. ${ }^{12}$

Also, by conducting major attacks behind enemy lines (i.e., in Western nations), they put on a spectacular show of force, which drives the majority of the donations to the network. ${ }^{13}$

The jihadists' primary long-term goal is to restore a devout Islamic caliphate by politically uniting all countries with a Muslim majority in an Islamic realm through a monolithic Islamic religious and social movement. The desired end state is the caliph-

11 Norwegian Defense Research Establishment, "FFI Explains al-Qaida Document" (19 March 2004); available at www.mil.no/felles/ffi/start/article.jhtml?articleID=71589.

12 Ziauddin Sardar, "Pakistan: The Taliban Takeover," New Statesman (30 April 2007); available at www.newstatesman.com/asia/2007/04/pakistan-taliban-afghanistan.

13 Yassin Musharbash, The New al-Qaida: Insights of a Learning Terror Network (Bonn: Spiegel Online, 2006). 
ate's rule worldwide. ${ }^{14}$ The Taliban limit their focus on Afghanistan and Pakistan. In an interview in 2008, Hakeem Ullah Mehsud, believed to be right-hand man of Taliban chief Baitullah Mehsud, said that his group "will capture Pakistan if Islamabad continues to support NATO's operation in Afghanistan. In fact, the Taliban will not hesitate in taking over Peshawar, Hangur, and eventually the whole of Pakistan." 15

\section{The Jihadists' Communication Goals}

\section{Propagation}

The jihadists' communication strategy is inseparable from their political strategy, as their terrorism and rhetoric alike work toward their common goals and desired end state. Consequently, their communication goals are based on their short-, mid-, and long-term goals.

Their primary long-term strategic communication goal is the propagation and enlargement of their movement through the global dissemination of information among receptive Muslim audiences (or regional audiences, in the case of the Taliban). The terrorist communication strategy aims ultimately at a fundamental restructuring of the political discourse and identity of the Islamic world.

\section{Legitimization}

The legitimization of the Taliban and jihadist terrorist movement and methods-establishing its social and religious viability while they engage in violent acts - requires a continuous communication effort. Their violent methods and killing of innocent people inevitably face contradictions with some of the core tenets of Islam. This built-in drag on the organization's legitimacy ${ }^{16}$ can in the long run only be circumvented through an unceasing communication effort in which, as Weimann notes, "Violence is presented as a necessity foisted upon the weak as the only means with which to respond to an oppressive enemy."17

Therefore, legitimacy and the ostensible demonstration of compliance with Islamic law are prominent in their communication strategy. The utopia of their aimed-for end state and their Islamist-jihadist worldview fulfills a significant purpose: the utopia is not only the goal of their violent action, but also its moral and religious justification. They try to portray their movement as one made up of freedom fighters, forced against their will to use violence due to a ruthless enemy that is crushing the rights and dignity of their community. This makes legitimatization of their terroristic deeds their second strategic communication goal.

14 Ayman Al-Zawahiri, "Letter from al-Zawahiri to al-Zarqawi," released by the Office of the Director of National Intelligence, 11 October 2005; available at www.globalsecurity.org/ security/library/report/2005/zawahiri-zarqawi-letter_9jul2005.htm.

15 Hakeem Ullah Mehsud, "Taliban Vows to Take over Pakistan," ZeeNews.com (1 December 2008); available at www.zeenews.com/world/2008-12-01/487646news.html.

16

17 Gendron, "Trends in Terrorism Series: Al-Qaeda: Propaganda and Media Strategy." Gabriel Weimann, www.terror.net - How Modern Terrorism Uses the Internet, Special Report 116 (Washington, D.C.: United States Institute for Peace, March 2004), 6. 


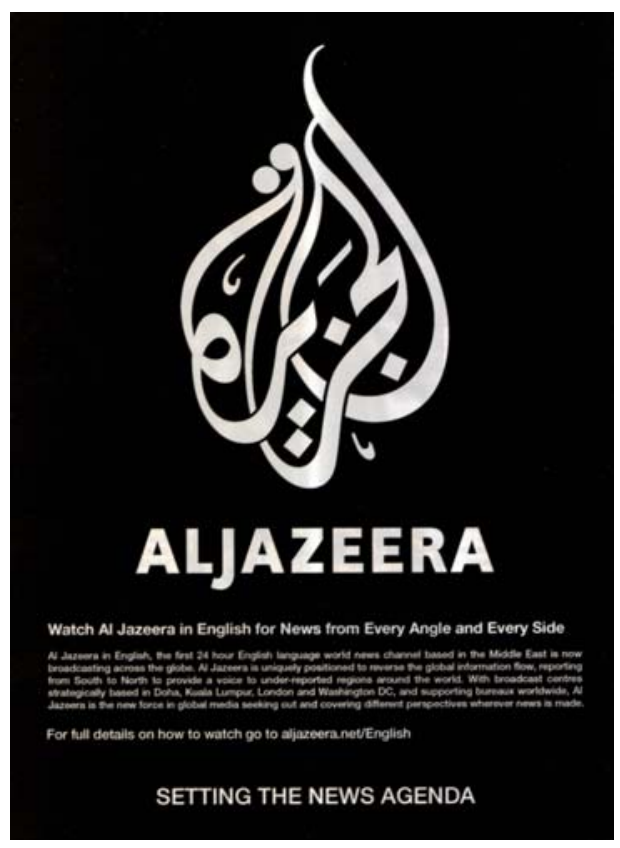

Figure 2: Al-Jazeera TV Advertisement (from www.freshglue.com/fresh_glue/politics).

\section{Intimidation}

The coercion and intimidation of opponents both nearby and abroad is the Taliban and jihadist terrorists' third main strategic communication goal. The near enemy is composed of apostates, or secular Muslim regimes, especially ones that receive Western support. The far enemy is, in their view, made up of Jews, unbelievers, and Western society as a whole. They try to manipulate the near enemy in order to reach their mid-term political goal of removing the near enemy from power. They also try to intimidate the far enemy into a complete withdrawal from the Muslim world and a removal of support from secular Muslim regimes (i.e., the near enemy). The desired end state - global rule by a devout Islamic caliphate - is the all-embracing long-term communication goal.

\section{Communication Infrastructure}

\section{Traditional Communication Methods}

During the 1990s, Islamist terrorists communicated with their audience using more traditional means, such as storytelling, journalist interviews, fax, face-to-face propaganda, and even press conferences. At the end of 1998, there was a shift in the primary means of strategic communication due to technological advances and the rise of the AlJazeera television network (see Figure 2). ${ }^{18}$ Al-Jazeera became a channel for broadcasting jihadist messages to the Muslim world, and would then provide the tapes to $\mathrm{CNN}$ and other international news organizations. ${ }^{19}$ To a certain extent, the media mutated from its role as a critical observer and reporter and came to play an increasingly active role as a conflict participant. ${ }^{20}$ Angela Gendron quotes an Al Qaeda spokesman in describing this shift:

\footnotetext{
18 Magdalena Wojcieszak, "Al Jazeera: A Challenge to the Traditional Framing Research," International Communication Gazette 69 (2007): 115-28.

19 Gendron, "Trends in Terrorism Series: Al-Qaeda: Propaganda and Media Strategy."

${ }^{20}$ Guy Golan, "Inter-Media Agenda Setting and Global News Coverage," Journalism Studies 7:2 (2006): 323-33.
} 
Sheikh Usama knows that the media war is not less important than the military war against America. That's why Al Qaeda has many media wars. The Sheikh has made Al Qaeda's media strategy something that all TV stations look for. There are certain criteria for the stations to be able to air our videos, foremost of which is that it has not taken a previous stand against the mujahedeen. That maybe explains why we prefer Al-Jazeera to the rest. ${ }^{21}$

The jihadist terrorists carefully tapped into the "Al-Jazeera narrative," sounding strictly those themes most likely to appeal to a pan-Muslim audience. The main themes are the call for jihad against Israel, the end of the occupation of Palestine, the Arabian Peninsula, and Afghanistan, and the end of the U.S. presence in the Persian Gulf region. Since the last Iraq war, themes have also included a call against the U.S. occupation of Iraq, an end to drone attacks in Pakistan and a call against the corruption in existing Islamic regimes, including Pakistan.

\section{New Media}

After 11 September 2001, jihadist terrorists expanded their communication infrastructure and methods of communication considerably. That year saw the formation of the $A s-S a h a b$ (The Cloud) Islamic Media Publication Company. It is essentially the main entity of the media production division of Al Qaeda, which relies heavily on the Internet. It produces video files of interviews, documentaries, speeches, or news programs. All known speeches by the senior leadership of the original Al Qaeda released after June 2006 carry the $A s$-Sahab logo. The frequency, quality, and style of the video messages are getting more and more professional and the techniques used are increasingly sophisticated. The media rhetoric is mainly built around the visual component of a story. Email, Skype, and other VOIP programs are increasingly using visual modes of communication, and the jihadist terrorists utilize this technology abundantly in conjunction with the Internet. ${ }^{22}$ English, either spoken or in subtitles, is regularly the language of choice. Other subgroups use different modus operandi and video production features like subtitles and logos. By creating their own training and operational video tapes, the terrorist groups support organizational learning in several ways, providing the groups producing the video with firsthand experience (learning by doing) and the audience viewing the video with secondhand experience (learning by imitation) ${ }^{23}$

The new media provide the vehicle for the dissemination of the terrorist message. The greater the violent audacity and the larger the scale of the cold-blooded brutality of the terrorist act, the more coverage it usually receives. Thereby the terrorists reach the global public, including any desired audience. They recognized the revolutionary

21 Gendron, "Trends in Terrorism Series: Al-Qaeda: Propaganda and Media Strategy."

22 Gustavo Cardoso, "From Mass to Networked Communication: Communicational Models and the Informational Society," International Journal of Communication 2 (2008): 587-630.

23 Arab Salem, Edna Reid, and Hsinchun Chen, "Content Analysis of Jihadi Extremist Groups' Videos," in Terrorism Informatics: Knowledge Management and Data Mining for Homeland Security, ed. Hsinchun Chen, Edna Reid, Joshua Sinai, Andrew Silke, and Boaz Ganor (New York: Springer, 2008), 267-284. 
significance of this shift in the media infrastructure, perceptive of the fact that the use of strategic communication management can constitute a weapon of equal status with that of conventional armed forces. In the media, international terrorism has at its disposal an instrument of substantial power with which it can compensate for a significant element of its disadvantage in military might. Terrorists have adapted innovative twenty-first century information and communications technologies and the associated infrastructure to maximize the psychological impact of their operations and communiqués through the use of video messages. ${ }^{24}$

The jihadist terrorist strategy is inextricably rooted in their extensive use of new communication media. This is underlined by the organizational structure adopted by the jihadists in the mid-1990s through late 2001, which incorporated communication and media functions. The formal structure included political, military, and information committees. The political committee was responsible for wider political relations and the pan-Muslim jihad movement. The military committee conducted armed operations. The information committee provided the "[m]eans of communications setup in all categories of Islamic people, taking great pains in making it aware of its enemies' plans, aspiring to concentrate all of the scientific, legal, and jihad capabilities in the first level in order to obstruct on line in front of the alliance of the infidel and the ugly ones." 25

\section{Global Mass Media and the Internet}

This organizational structure changed after the loss of Afghanistan as a physical base. The conversion from a clandestine organization to a decentralized, open network organization represented the Islamist terrorist movement's only possible means of survival. Their previous dependence on traditional broadcast mass media was replaced and its impact was multiplied by their adoption of the Internet as their medium of choice and supplemented by the dissemination of DVDs and night letters. The aim of such communication efforts is to effect the transformation of dispersed followers and sympathizers in the Muslim community into self-made terrorists. The volunteer legwork by terrorist sympathizers is therefore highly welcomed.

After losing their base in Afghanistan, the jihadist terrorists decreased the size of their attacks to a target victimization of around 50 to 200 casualties, like the bombing of the Marriott Hotel in Islamabad on 20 September 2008. The blast of $600 \mathrm{~kg}$ of RDX and TNT occurred hours after Pakistan's new president, Asif Ali Zardari, told the Pakistani parliament that the country would continue its fight against terrorism. The terroristic act occurred a few hundred yards from the prime minister's house, where

24 Tanja Storsul and Anders Fagerjord, "Digitization and Media Convergence," in The International Encyclopedia of Communication, Vol. IV, ed. Wolfgang Donsbach (Oxford: Blackwell, 2008), 1319-1323.

25 Steven R. Corman and Jill S. Schiefelbein, "Communication and Media Strategy in the Islamist War of Ideas," in Weapons of Mass Persuasion, Strategic Communication to Combat Violent Extremism, ed. Steven R. Corman, Angela Trethenwey, and H. Lloyd Goodall, Jr. (New York: Peter Lang, 2008), 73. 
high-level government officials were dining after the president's address. This dinner had been moved from the Marriott Hotel at the last moment. ${ }^{26}$ The same rough target casualty rate holds true for the attacks in Mumbai by Lashkar-e-Taiba, ${ }^{27}$ the terrorist group presumably responsible for the deadly attacks in November 2008. The Mumbai attacks were a series of eight coordinated attacks across Mumbai, India's financial capital and its largest city, killing at least 101 people. The attacks began on 26 November 2008 and ended on 29 November, when Indian security forces regained control of the attack sites. The complexity of the operation - the coordinated beach landing, the use of GPS and Google Maps - showed that the level of sophistication of terrorist attacks is continuously increasing. ${ }^{28}$ Bigger and more complex operations with thousands of victims, like the attacks on New York and Washington in September 2001, are no longer the operational norm. The risk that operations of this scope could be detected and stopped by law enforcement and intelligence agencies is too great.

Jihadist terrorists now resort to the tactic of "guideless resistance," in which responsibility for planning operations rests solely with the decentralized actor (Abu Musab al Suri wrote a lengthy essay on this scheme). ${ }^{29} \mathrm{Al}$ Qaeda concentrates on producing abstract directives and motivational calls in order to steer their movement. Processes running in parallel and coordinated via the World Wide Web enable the jihadist terrorists to survive as a loosely connected network.

The emergent digital technologies expanded these terrorists' communicative possibilities. By using the global mass media and the Internet as their main communication infrastructure, $\mathrm{Al}$ Qaeda survives as a jihadist terrorist organization through publishing written statements, blogs, ${ }^{30}$ articles by ideological leaders, and online magazines. ${ }^{31}$ The jihadist terrorists profit from the fact that the world of mass communication is evolving into a world of networked mediated mass communication, where different mediated technologies combine interpersonal mediation devices with mass communication ones. Those different media are connected through inter-personal devices such as mobile phones, iPods, WiFi, etc., along with the World Wide Web. The fusion of interpersonal communication and mass communication-connecting audience members who all can

26 Overseas Security Advisory Council, "Warden Message: Powerful Bombing at Islamabad Marriott in Pakistan," Consular Affairs Bulletins, 20 September 2008; available at www.osac.gov/ Reports/report.cfm\%3FcontentID\%3D90730+osac+Marriott+bombing\&hl=de\&ct=clnk\&cd=1 $\& \mathrm{gl}=\mathrm{de}$.

27 Lashkar-e-Taiba, that grew out of the 1980s resistance to the Soviet occupation of Afghanistan, has developed ties to al-Qaida. India accuses it of involvement in a string of terrorist attacks on its territory and alleges that Pakistani intelligence continues to back it - a charge vehemently denied in Islamabad.

28 "Mumbai Rocked by Deadly Attacks," BBC News Online (29 November 2008); available at http://news.bbc.co.uk/2/hi/south_asia/7751160.stm.

29 Jessica Stern, "The Protean Enemy," Foreign Affairs 82:4 (July/August 2003); available at www.foreignaffairs.com/articles/58995/jessica-stern/the-protean-enemy.

30 Douglas Kellner, "War Correspondents, the Military, and Propaganda: Some Critical Reflections," International Journal of Communication 2 (2008): 297-330.

31 Europol, EU Terrorism Situation and Trend Report (2007). 
also be publishers or broadcasters at the same time via the World Wide Web-enhances the resonating cavity available to terrorists and greatly increases their access to audiences. $^{32}$

Additionally, almost every major news organization offers visitors to its Web site the opportunity to upload content that, if compelling enough, will be featured online as user-generated content. Even newspapers regularly cite reader comments and depend on blog members as sources of cutting-edge social and political news. This user-generated content is now a fundamental component of the global communication network. ${ }^{33}$ However, this use of the Internet also poses a dilemma. It is a major challenge to control a decentralized, amorphous, and secretive organization, orienting it to a common objective via the Internet while also maintaining organizational security. ${ }^{34}$

Dictatorships and totalitarian systems also pose challenges to terrorists who are trying to disseminate their messages. Under most dictatorial regimes, the life of an individual person has far less value. The spread of information about a terrorist act via the media can be suppressed in dictatorships by government means, so that the terrorists lack access to their decisive weapon: the mass media. Hence, terrorist acts are more effective in democracies. Democracies offer the ideal basic conditions for terrorism. Obviously, the principles of a democracy and the associated social structures represent for terrorists the functional equivalent of marshes and inaccessible mountain regions for partisans. In particular, the broadcast media and the Internet enable terrorists to thrive in a cancerous manner in the spaces created by the freedom that democracies provide - the very freedoms that Islamist terrorists seek to abolish. ${ }^{35}$ Even though mainstream press outlets tend to adhere mainly to official news sources, the terrorist message still receives abundant coverage. There is always the imminent danger that the mainstream press will become the outlet for the state's or the terrorists' "spin" if their research and investigation does not provide the necessary intellectual context and depth.

The intensive, sometimes obsessive coverage in the media given to a terrorist act generates the desired psychological effect. ${ }^{36}$ Terrorist actions are planned and organized in a manner that causes a strategically maximum communicative effect, while requiring minimal resources. Hence, based on a strategic communication plan and precise planning and consideration of the transmitting time, considerations of communication strategy take place well in advance of a terrorist attack.

The increasing globalization of the media and satellite reporting as well as the rapid development of the Internet have extended the scope of the terrorists' potential audience,

32 Cardoso, "From Mass to Networked Communication."

33 Amelia H. Arsenault and Manuel Castells, "The Structure and Dynamics of Global Multi-Media Business Networks," International Journal of Communication 2 (2008): 707-48.

34 Corman and Schiefelbein, "Communication and Media Strategy in the Islamist War of Ideas."

35 Frank Leptien, "Terrorismus für die Medien? Terrorismus durch die Medien? (Terrorism for the Media? Terrorism by the Media?)," Risser Einblicke 10/11 (2002).

36 Elihu Katz and Tamar Liebes, "'No More Peace!' How Disaster, Terror and War Have Upstaged Media Events," International Journal of Communication 1 (2007): 157-66. 
and show the determining innovation of the terrorist use of force. The symbiotic relationship between terror events and the media is apparent: the perpetrators would have far less impact without media publicity, and the media can hardly be expected to resist reporting on terror events. ${ }^{37}$ The marathon coverage of terror events may deprive the journalist of the time and distance he or she needs to research, investigate, and edit. An economic approach and an institutionalized perspective can help in understanding media events. They can be analyzed as products and outcomes of economic strategies whose aim is the accumulation of economic or symbolic capital, or the transformation of one type into the other. ${ }^{38}$

The fusion of the Internet and satellite television (IP TV) will lead to a convergence of different media, thereby strengthening this effect even further. This offers terrorists expanded possibilities to influence and manipulate audiences. Terrorists already make abundant use of the Internet for internal and external communication. They raise capital, franchise their brand names, recruit followers, ${ }^{39}$ find partners and suppliers, provide training materials through their online library, and manage operations. ${ }^{40}$ Terrorists capture information about the users who browse their sites. Users who seem most interested in their terroristic cause or well suited to carrying out its work are then contacted.

Thanks to the communication possibilities of the Internet, jihadist terrorist groups have become more numerous, agile, and well coordinated. Decades ago, before terrorism became an international phenomenon, local and regional media played a subordinated role. They were of limited use to jihadists, due to the governments' ability to control their appearance in the media:

This was done by legislation, by putting pressure on the national media ... over limiting exposure to terrorists. ... The situation in which both terror and media were operating within the nation's boundaries made it possible for governments to limit the terrorists' capacity to exploit the media for creating public anxiety, enhancing their bargaining power while holding hostages, or communicating with their own supporters. $^{41}$

This changed dramatically with the increasing interlinking of terrorism and the technological advancement of the media and its communication infrastructure. The media's worldwide "live reporting" via satellite TV has created the stage for a global media presence for the jihadist terrorists: "The automatic, universal adoption of the genre

37 Ibid.

38 Benjamin Krämer, “The Economy of Media Events: Theory and Examples," International Journal of Communication 2 (2008): 909-24.

39 Timothy L. Thomas, Cyber Silhouettes: Shadows over the Information Operations (Fort Leavenworth, KS: Foreign Military Studies Office, 2005).

40 Gendron, "Trends in Terrorism Series: Al-Qaeda: Propaganda and Media Strategy."

41 Allan Stuart and Barbie Zelizer, Reporting War: Journalism in Wartime (New York: Routlege, 2004), 57. 
of breaking new - that is, live marathonic broadcasting during, and in the wake of, a multi-victim attack - facilitates the upgrading of terrorists to superstars." 42

\section{Jihadist Media Structure}

For years, terrorists could rely on an almost streamlined Islamic media infrastructure, which willingly conveyed the desired messages and videotapes and helped terrorist groups shape a "brand name." Until the advent of the Internet, terrorists focused their attention on television, radio, or the print media. But these traditional media have "selection thresholds," which are multi-stage processes of editorial selection over which terrorists have no control. ${ }^{43}$ In addition to this obstacle, by early 2003 the media environment in the Arab world had begun to fragment, becoming increasingly crowded and competitive. A growing array of satellite television stations began to ensure competition and therefore a diversity of opinion, which hampers the communication strategy of the terrorists on the TV front. Arab television stations and their voices seem to be more capable of swaying the Muslim population away from jihadism than do the public diplomacy efforts of the Western nations.

The quantity and volume of anti-jihadi voices in the Arab media have dramatically increased since 2003, with every Al Qaeda-linked terror attack now being met by a chorus of Arab criticism and condemnation. Public opinion polls have shown steep declines in support for Al Qaeda, particularly in countries directly affected by its terror attacks. Arab satellite television became one of the strongest forces today pushing for change in the region, and represents one of the biggest obstacles to Al Qaeda's agenda of imposing a monolithic Islamic identity through a streamlined Muslim media voice. It therefore poses the greatest challenge to the terrorists' political vision, and accelerated the use of the Internet as an information-spreading platform to compensate for the loss of satellite TV as a friendly media outlet. This further entrenches the Internet as the key enabler and main strategic communication infrastructure asset for terrorists. ${ }^{44}$ As Abu Omar expressed it, "We are the energy behind the path to jihad. Just like the jihadis reached their target on September 11, we will reach ours through the Internet."

2003 also saw the publication of Sawt al-Dschihad, the first jihadist terrorist magazine published on the Internet. Even though its last issue appeared in April 2005, it found many imitators. Following its example, numerous terrorist groups in Iraq, North Africa, and Afghanistan began publishing magazines, which provoked a warning not to abuse brand names. In 2004, Saudi Al Qaeda said that the title "Voice of the Jihad" is

42 Ibid., 81.

43 Gabriel Weimann, www.terror.net - How Modern Terrorism Uses the Internet.

${ }^{44}$ Steven R. Corman and Jill S. Schiefelbein, "Communication and Media Strategy in the Jihadi War of Ideas," Consortium for Strategic Communication, Arizona State University, Report \#0601 (20 April 2006); available at http://www.asu.edu/clas/communication/about/csc/ publications/jihad_comm_media.pdf.

45 Hassan Fattah, "Al-Qaeda Increasingly Reliant on Media," New York Times (30 September 2006); available at www.nytimes.com/2006/09/30/world/30jordan.html. 


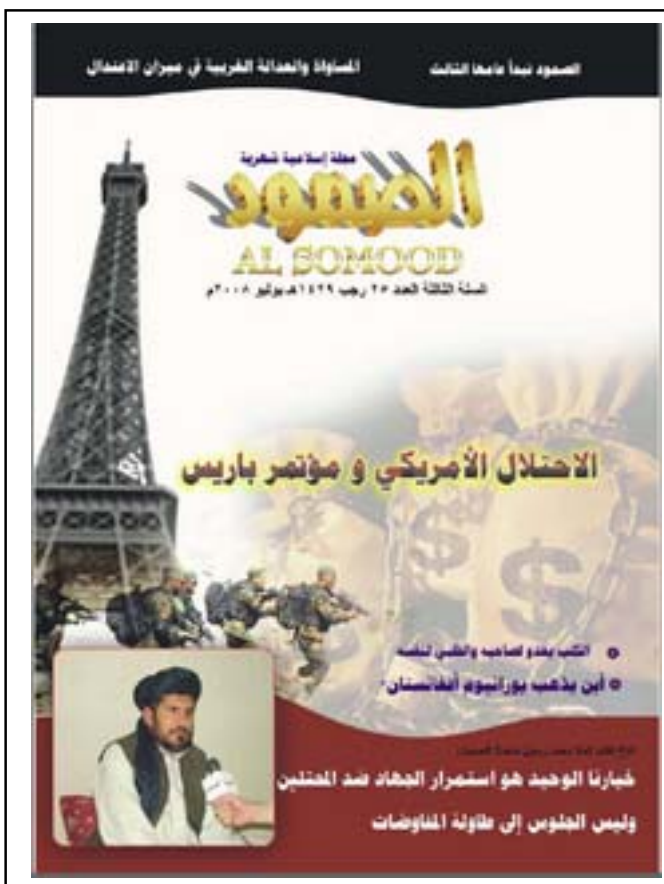

Figure 3: Al-Somood Magazine (from http://img299.imageshack.us/img299/7752/ 4545454gq0.jpg). the property of Saudi Al Qaeda, and called on imitators to develop and franchise their own brand names. ${ }^{46}$

In the jihadist terrorist web infrastructure, ${ }^{47}$ websites suddenly emerge, frequently modify their formats, swiftly disappear, or change their online address. ${ }^{48}$ More recently, the use of static websites has declined in light of the fact that these websites are still relatively easily closed down by hackers or law enforcement agencies. Now terrorists utilize online forums and blogs as a more secure way of disseminating their propaganda material. These forums offer access to files stored on free storage sites. Since this material is spread over numerous web servers located all round the globe, blocking access to these files becomes virtually impossible. ${ }^{49}$

\section{Excursion: The Taliban Communication Strategy}

In Summer 2006 the Taliban began publishing a magazine titled Somood. By March 2009 , the thirty-third issue of this online magazine had been released. ${ }^{50}$ In an article published in January 2008, the magazine clearly explained the strategic communication activities of the Taliban:

\footnotetext{
${ }^{46}$ Musharbash, "The New al-Qaida: Insights of a Learning Terror Network."

${ }^{47}$ Hsinchun Chen, Edna Reid, Joshua Sinai, Andrew Silke, and Boaz Ganor, eds., Terrorism Informatics: Knowledge Management and Data Mining for Homeland Security (New York: Springer, 2008).

Weimann, www.terror.net - How Modern Terrorism Uses the Internet.

49 Europol, EU Terrorism Situation and Trend Report, 2007.

${ }^{50}$ CBS News Investigates, "Taliban Pledges to Cut NATO Supply Route, Make 2009 a 'Bloody' Year for U.S. Forces," March 2, 2009, available at www.cbsnews.com/blogs/2009/ 03/02/monitor/entry4839147.shtml.
} 
Since its inception as a military jihadi movement, the Taliban Islamic movement has recognized the extraordinary importance of the news media in deciding [the outcome of] conflicts, in particular, ideological conflicts. It is convinced that the media are among the most important elements of psychological warfare - and the war of morale, which is by no means less important than the field war. Accordingly, the movement undertook to begin its media activity, together with its military activity, against the invading crusader forces at the time of the latter's invasion of Afghanistan. The movement appointed a unit consisting of the journalistic cadres who formerly occupied important media positions within the Government of the Islamic Emirate of Afghanistan. The [media] unit officially began its journalistic activities on 23/09/2002; the activities consisted of the following:

1. The setting up of an internet website, speaking on behalf of the Islamic Emirate.

2. Issue of the monthly magazine Sirk in the Pashtu and Dari languages.

3. The quarterly magazine Murshal [The Trench], specializing in the publication of military news and reports.

4. Issue of the weekly newspaper ad-Damir [The Conscience] in Pashtu and Dari.

5. Publication and distribution of CDs containing jihadi films.

6. Publication and distribution of [audio] tapes of jihadi songs and [news] reports.

7. Contact with both local and world [TV] channels and other news media.

8. The collection and gathering of field news, then the translation thereof into Arabic, English and Urdu.

9. Translation and publication of Islamic books, especially those concerning jihad and resistance [to occupation]. ${ }^{51}$

Until November 2006, the Taliban communication strategy was not yet effectively utilizing video as a medium. This changed starting in December 2006. The communication strategy of the Taliban became an even more vital component of their asymmetric war. After sending representatives to Iraq to learn how Al Qaeda's video production arm Al Sahab operates, they started to apply the knowledge they gained in early 2007 through a concerted Taliban "hearts and minds" campaign, which saw an increase in the frequency and quality of their videos.

In April 2007, the Taliban started utilizing embedded journalists. In June 2007, a Pakistani journalist filmed a Taliban suicide graduation ceremony. Videos of this graduation were circulating when the new Taliban commander, Mansor Dadullah, conducted an interview with Al-Jazeera. "Throughout 2008 the momentum was maintained and in autumn of that year the Taliban provided Al-Jazeera International ... fourteen

51 Al-Samood Magazine, "The Media Activities of the Taliban Islamic Movement" (17 January 2008); available at http://74.125.77.132/search?q=cache:6rvuib6b8vMJ:worldanalysis.net/ postnuke/html/index.php\%3Fname\%3DNews\%26file\%3Darticle\%26sid\%3D731+taliban + magazine + somood\&cd $=3 \&$ hl $=$ en $\&$ ct $=$ clnk. 
video tapes of their operations against coalition troops." ${ }^{, 52}$ These videos were produced in the Taliban's media center, which was part of a three-part documentary aired by AlJazeera. ${ }^{53}$

\section{Target Audiences and Communication Channels}

While some propaganda messages are intended for a broad audience, the majority are tailored to a particular target group. The messages, the channels by which these messages are communicated, and the languages they use are customized to suit the special needs of the target group. The terrorists select and segment the strategically desired target audience, the transmitting medium, and the targets for destruction. They determine the location and timing of their actions to satisfy media criteria for newsworthiness that fit in with the media's deadlines and news cycles in order to effectively reach the desired audience. The actual violent operation is embedded within their strategic communication efforts. Herein the Internet is becoming increasingly important as a communication channel. It offers easy access, little or no regulation and censorship, potentially huge audiences, anonymity, and a rapid flow of information, all at relatively little expense. ${ }^{54}$

Jihadist terrorists have become extremely adept at exploiting the unique attributes of the Internet. It offers the possibility to communicate in near real time. The Internet is also used extensively as a terrorist knowledge transfer base and education medium for the movement's own followers. Further, they use the medium extensively for command and control, to gather intelligence, and to distribute information among their sympathetic audience. The Internet has enabled the rise of numerous loose and decentralized terrorist networks and enables terrorist groups to operate like decentralized franchises or freelancers. This revolutionary electronic medium enables the terrorists to operate as virtual transnational organizations and reach their audiences around the globe to maintain group identity, indoctrinate new members, and demonstrate the implementation of its revolutionary ideology and principles. ${ }^{55}$ The Internet, as an uncensored medium, carries information regardless of its validity or potential impact. It allows even small groups to amplify their messages and exaggerate their importance and the size of the threat they pose. ${ }^{56}$

Jihadist terrorist groups also use the Internet as a mass medium to exploit the abundant possibilities to sow disinformation, undermining diplomatic and military efforts and improving their own operational effectiveness. Consequently, some of their followers specialize in information warfare, and regularly claim responsibility for attacks that have occurred or will take place. The grand masters in this discipline are the Abu

52 Steve Tatham, "Strategic Communication: A Primer," paper published by the Advanced Research and Assessment Group of the British Defence Academy (December 2008), 22; available at www.isn.ethz.ch/isn/Digital-Library/Publications/Detail/?ord516=OrgaGrp\&ots591= 0C54E3B3-1E9C-BE1E-2C24-A6A8C7060233\&lng=en\&id=94411.

54 Weimann, www.terror.net - How Modern Terrorism Uses the Internet.

${ }^{55}$ Gendron, "Trends in Terrorism Series: Al-Qaeda: Propaganda and Media Strategy."

56 Weimann, www.terror.net - How Modern Terrorism Uses the Internet. 
Hafs al Masri brigades. Every time these dubious brigades have claimed responsibility for an attack, the news agencies and security services jumped, although to this day not one brigade member has been caught who had any connection to the execution of an attack. They even claimed to be responsible for the power outages in August 2003 in parts of the United States. ${ }^{57}$

\section{The Ummah as an Audience}

The target audiences of the jihadist terrorists can be divided into two groups: those who lie outside and inside the Ummah.

The Ummah Outsiders. Ummah is an Arabic word used to describe the Muslim diaspora or "Community of Believers," and thus the global community of Muslims. This group can be segmented into insiders and outsiders of the jihadi audience. ${ }^{58}$ The outsiders include two groups: the sympathizers and the neutrals. They consist of the Muslims who could potentially be persuaded to become ummah insiders. In the long run, major portions of this audience are needed to realize the desired end state of a global devout Islamic caliphate. ${ }^{59}$ This means in consequence that the terrorists' primary target audience is neither a minority of radicalized jihadists nor the public of the Western nations, but the vast majority of the Muslim public. The main communication channels for reaching this vast audience consist of face-to-face methods, utilizing prayers, speeches, and sermons in mosques and madrassas, the mass media, and increasingly, the Internet.

The Ummah Insiders. The insiders consist of two groups as well: the supporters and followers. They are committed Muslim radicals who provide operational, financial, or administrative support to the global jihadist terrorist movement. ${ }^{60}$ For this audience, the main communication channel is the Internet, with the mass broadcast media providing a secondary avenue. But reaching both elements of the Ummah is crucially important to the jihadist movement. As Ayman al-Zawahiri stated in July 2004: "We are in a battle, and more than half of this battle is taking place in the battlefield of the media.... (W)e are in a media battle for the hearts and minds of our Ummah." ${ }^{1}$

\section{The Adversary Outsiders}

This audience includes apostate secular Muslim regimes, sometimes referred to as troublemakers, and all unbelievers: the so-called crusaders, Zionists, apostates, Jews,

57 Yigal Carmon, “Assessing the Credibility of the Aub Hafs al-Masri Brigades' Threats," Inquiry \& Analysis: The Middle East Media Research Institute (10 August 2004); available at http://memri.org/bin/articles.cgi?Page=archives\&Area=ia\&ID=IA1 8504.

58 Corman and Schiefelbein, "Communication and Media Strategy in the Jihadi War of Ideas"; Gendron, "Trends in Terrorism Series: Al-Qaeda: Propaganda and Media Strategy." Corman and Schiefelbein, "Communication and Media Strategy in the Jihadi War of Ideas."

60 Ibid.; Gendron, "Trends in Terrorism Series: Al-Qaeda: Propaganda and Media Strategy."

61 Craig Whitlock, "Keeping al-Qaeda in His Grip, Al-Zawahiri Presses Ideology, Deepens Rifts among Islamic Radicals," Washington Post Foreign Service (16 April 2006); available at www.washingtonpost.com/wp-dyn/content/article/2006/04/15/AR2006041 501130_pf.html. 
and the West, of which the United States is considered the leader. These segments are further dissected into the near enemy (apostates, secular Muslim regimes) and the far enemy (Jews, unbelievers, and Western society). ${ }^{62}$ The preferred communication channel to reach these groups is the global mass media, with the Internet playing a secondary role.

\section{Findings and Recommendations}

A written Taliban or jihadist strategic communication management plan has not yet been intercepted. But that terrorists use strategic communication management techniques is certain, as this article has shown. They have defined their communication objectives, developed their communication tactics, and established the media strategies necessary to reach these communication goals. Many jihadist documents demonstrate that the jihadists do analyze their communication and media operations in order to enhance their overall effect on the larger jihadist mission. The fact that the self-proclaimed jihadist terrorists evaluate the effectiveness of their communications campaigns and even elaborate theoretically about how efficient their operations are underscores their professionalism and the depth of their conviction. ${ }^{63}$ Systematically practicing afteraction reviews, they usually record the event on scene and monitor the media coverage and its spread via the Internet thereafter.

The mass media, and especially the Internet, have become the key enablers and the main strategic communication assets for terrorists, and have ensured them a favorable communication asymmetry, which compensates for their military disadvantage. Taliban and Jihadist terrorists place a great deal of emphasis on developing comprehensive communication strategies in order to reach their desired short-, mid- and long-term goals and desired end states, and they carry them out in a rigorous and sophisticated manner. Their communication goals aim at legitimizing their methods, propagating their membership, and intimidating their opponents. They customize their strategies based on thorough audience research, and shape their messages and media choices accordingly, following the rules of any successful public relations campaign. Their skillful use of many forms of electronic media has enabled them to promote their message and continually win new adherents to their cause.

This information asymmetry must be undermined in order to counter the threat of a growing radicalization of the Muslim community. This can best be accomplished by calling the Taliban and jihadists' credibility into question, while ensuring the trustworthiness of Western media sources. It is possible to counteract the three primary communication goals of the terrorists that have been outlined in this essay: legitimization, propagation, and intimidation. Next to eliminating the root causes and alleviating the underlying conditions, motivators, and enablers of terrorism-e.g., rooting out the terrorists' physical bases - developing an effective counter strategic communication

62 Ibid.

63 Corman, Trethenwey, and Goodall, eds., Weapons of Mass Persuasion: Strategic Communication to Combat Violent Extremism. 
plan that exploits weaknesses and contradictions in the jihadists' use of strategic communication management techniques is a vital step in winning the asymmetrical conflict with terrorists.

This communication plan has to be embedded into a greater strategic plan. As a comprehensive unified approach, this plan needs to counter terrorism by achieving a favorable asymmetry in all five dimensions of modern warfare - knowledge, strength, time, space, and ingenuity - and at three levels: First, at the tactical level, an operative coercive mechanism for deterrence (denial of opportunity) is needed to delink the terrorist action from its intended victims. Second, at the operational level, we require a mechanism of denial of capability, in order to disrupt the terrorists' organizational recruitment and training processes, their access to weapons and sanctuary, their communications, and their finance networks. The third requirement is a mechanism at the strategic level: the denial of objectives. In all of these steps, the marginalization of terrorist messages is a major necessity, and developing a strategic counter-communication plan is a vital part thereof. ${ }^{64}$ All this should include efforts to address community key leaders to provide unaffiliated, trusted engagement as well as affiliated engagement to ensure a "viral" dissemination effect of our messages and narratives.

\section{Intensify the Research on Root Causes}

The first phase in developing an effective counter-communication plan is research. The goal of this phase is to take a comprehensive look at all the variables that will have an impact on the development of a strategic counter-communication plan. To attain a complete picture of the root causes that are driving the terrorists, it is crucial to research and synthesize the causes at different levels. This includes mapping the spectrum at the individual, group, societal, and governmental levels. Addressing the underlying root causes that facilitate recruitment and support for terrorists-such as the prevalence of regimes that stifle opportunities for educated youth to attain socio-economic and political advancement - is an elementary part of such an effort. The research must also look at a range of coercive and conciliatory measures that address the general and specific root causes that give rise to the jihadist terrorist networks. The root causes of terrorism are generally not static but rather dynamic, and are a fundamental part of the center of gravity in the societies that give rise to terrorist movements. In the long run, Taliban and jihadist radical revisionism cannot succeed, unless its strategic communication management approach can win substantial support from the local and global Muslim community.

But winning such support is unlikely. The fourteenth-century ideology promoted by the Taliban and jihadist terrorists and the indifferent killing of innocent people, both Muslims and unbelievers, holds little appeal for the majority of Muslims. They have no wish to live under a repressive theocratic dictatorship in a new Islamic caliphate striving for global domination. Furthermore, Arab satellite television has become one of the

${ }^{64}$ James M. Smith and Brent J. Talbot, "Terrorism and Deterrence by Denial," in Terrorism and Homeland Security - Thinking Strategically about Policy, ed. Paul R. Viotti, Michael A. Opheim, and Nicholas Bowen (London: CRC Press, 2008). 
main obstacles to the jihadist terrorists' communication goals of imposing a monolithic Islamic identity through a streamlined Islamic media voice. There is a decline in the Muslim support for jihadist terrorists and their deeds, particularly in countries directly affected by their indiscriminate terror attacks.

\section{Intensify the Research on the Main Communication Channel: The Internet}

As this article has shown, the main communication backbone for terrorist communication is the Internet-based World Wide Web. Therefore, this media outlet must be at the center of our research. Twitter, YouTube, and Facebook are becoming more and more important as shapers of opinion and providers of believable news (as was witnessed by recent events following the disputed elections in Iran). There is an imminent danger that these new media are only viewed as leisure activities and not as avenues for telling a story or communicating to specific audiences. We must fight the terrorists with their own "weapons" by utilizing their main communication channel against them. In order to get a comprehensive overview, there is a need to expand primary research involving access to and interviews with terrorists as well as to broaden the systematic discussion and dissection of terrorism research. It is a primary necessity to investigate new networked communication channels. ${ }^{65}$ In order to analyze the main terrorist communication channels, a systematic, integrated approach to the study of the terrorist web infrastructure - a system that can be visualized as a network of hyperlinked communities - is necessary. This should include automated Web crawling techniques and the Dark Web Attribute System ${ }^{66}$ to study the extremist organizations' Internet presence. Additionally, since the Web-based jihadist terrorists' multimedia collections will increase, automatic extraction of structural and semantic content will be a crucial aide in the systematic analysis of the groups' modus operandi, violent events, learning styles, networks, and tactical operations. A semi-automated framework for blog analysis could be utilized to investigate the characteristic and structural relationships among the terroristic groups in blogs. ${ }^{67}$

\section{Develop a Story}

Steve Tatham writes, "Narratives are the foundation of all strategy. They are the organizing framework for policy and the definite reference for how events are to be argued and described. Their purpose is to bind together all of the actions of the government (possibly 'governments') when working in coalitions, and their representatives, under a common understanding." $" 68$ Even though the Internet is a key communication channel, not all Muslims have access to it. Just like our opponents, we need to tell real, not fic-

65 Cardoso, "From Mass to Networked Communication: Communicational Models and the Informational Society."

66 The Dark Web Attribute System is an integrated approach for identifying and collecting terrorist/extremist Web contents. It enables quantitative Dark Web content analysis from three perspectives: technical sophistication, content richness, and web interactivity.

67 These are just a few tools to help investigate the terrorist use of the World Wide Web. For a more comprehensive look into terrorism research, see Chen, Reid, Sinai, Silke, and Ganor, eds., Terrorism Informatics: Knowledge Management and Data Mining for Homeland Security.

68 Tatham, "Strategic Communication: A Primer," 9. 
tional stories, that rely on instincts, feelings, cultural commonalities, and shared narratives that will resonate and allow messages to emerge rather than to be stated. Along with all other communication channels, these stories also need to be channeled through local storytellers. We need to develop a "Western" narrative built around a core story of the Western world, including "sub-plots." The narrative must resonate with a multitude of audiences, and should allow the audiences to draw their own conclusions rather than overtly promote our "Western thinking" and the evil nature of the terrorists. Our values need to be embedded in these stories, which should transcend time and space and be enduring, while at the same time destroying the terrorists' credibility. This story must be a vital part of the development of a counter-strategic communication plan. The narratives should provide structure and relevance to the meaning of a particular situation, and the messaging should be connected to the over-arching narrative of the story.

\section{Develop an International Synchronized Strategic Counter-Communication Plan as an Integral Element of a Comprehensive Approach}

Based on these findings, and embracing the complexity of information flow, a strategic counter-communication plan has to be developed and constantly adapted in order to disrupt the opponents' favorable communication asymmetry. In order to successfully employ a strategic counter communication plan, it has to be woven into a comprehensive approach of coercive military ${ }^{69}$ and law enforcement measures and conciliatory political, diplomatic, and socio-economic measures. These measures and the counter-communication plan have to be synchronized at all levels of government (political, diplomatic, law enforcement, military, and intelligence) and with our partners and allies in order to harmonize international efforts within a grand strategy. ${ }^{70}$ This grand strategy - a comprehensive approach as security philosophy - is an all-embracing approach that can only be developed within networked security structures based on a comprehensive international security rationale that effectively combines civilian and military instruments. Data on terrorism research should, as far as possible, be made public and shared to reduce the "hidden knowledge" in disparate databases and disconnected researchers. We need to move from a "need to know" to a "need to share" mentality-that is, move away from risk aversion and information protection to more risk acceptance and information dissemination. By internationally democratizing data and integrating both qualitative and quantitative information, we can dramatically increase our knowledge and bring greater empiricism to this field of research.

69 On 19 September 2008, the U.S. Department of Defense released a "Military Contribution to Cooperative Security (CS) Joint Operating Concept," Version 1.0. Although this concept is a step in the right direction, it needs to be embedded in a grand strategy, which still has to be developed at the U.S.-national and international levels. 


\section{Conclusion}

Next to the priority of developing a grand strategy to combat Taliban and jihadist terrorists, we need to focus more international research resources on countering the operational effectiveness of terrorist use of the mass media and the Internet, in order to undermine jihadist terrorist strategic communication operations. We need to address the root causes and strike the center of gravity - the tipping point of Islamic societyby implanting narratives and messages and building critical mass and crossing the threshold, when the key target audience multipliers unleash a social epidemic in shifting views to turn the information asymmetry against the terrorists. ${ }^{71}$ If the terrorists' effective strategic communication management techniques - and in particular their use of the Internet - can be curtailed by a counter-communication plan embedded in a grand strategy as part of an internationally unified effort in all five dimensions of the battle space, the basis of their favorable asymmetry can be eroded. If jihadist terrorists can be prevented from finding new physical bases in safe havens or in ungoverned areas, including those on the World Wide Web, jihadism may ultimately prove to be yet another instance of fanatical backlash that eventually fades.

${ }^{71}$ Malcolm Gladwell, The Tipping Point: How Little Things Can Make a Big Difference (New York: Back Bay Books, 2006). 


\section{Bibliography}

Al-Zawahiri, Ayman. Letter from al-Zawahiri to al-Zarqawi. Office of the Director of National Intelligence, 2005.

Arsenault, Amelia H., and Manuel Castells. "The Structure and Dynamics of Global Multi-Media Business Networks." International Journal of Communication 2 (2008): 707-48.

Bockstette, Carsten, Walter Jertz, and Siegfried Quandt. Strategisches Informations- und Kommunikationsmanagement. Handbuch der sicherheits-politischen Kommunikation und Medienarbeit (Strategic Information- and Communication Management. Manual for the Military Communication and Media Work). Bonn: Bernard \& Graefe Verlag, 2006.

Bockstette, Carsten. "Terrorismus und asymmetrische Kriegsführung als kommunikative He-rausforderung (Terrorism and Asymmetric War Fighting as a Communicative Challenge)." In Strategisches Informations- und Kommunikationsmanagement. Handbuch der sicherheits-politischen Kommunikation und Medienarbeit (Strategic Information and Communication Management. Manual for the Military Communication and Media Work). Bonn: Bernard \& Graefe Verlag, 2006.

Cardoso, Gustavo. "From Mass to Networked Communication: Communicational Models and the Informational Society." International Journal of Communication 2 (2008): 587-630.

Carmon, Yigal. Assessing the Credibility of the Aub Hafs al-Masri Brigades' Threats. Inquiry \& Analysis: The Middle East Media Research Institute, 2004.

Chen, Hsinchun, Edna Reid, Joshua Sinai, Andrew Silke, and Boaz Ganor. Terrorism Informatics: Knowledge Management and Data Mining for Homeland Security. New York: Springer, 2008.

Corman, Steven R., and Jill S. Schiefelbein. "Communication and Media Strategy in the Islamist War of Ideas." In Weapons of Mass Persuasion, Strategic Communication to Combat Violent Extremism, 73. New York: Peter Lang, 2008.

Corman, Steven R., and Jill Schiffelbein. Communication and Media Strategy in the Jihadi War of Ideas. Consortium for Strategic Communication, Arizona State University, 2006.

EU Terrorism Situation and Trend Report, 2007. Europol, 2007.

Fattah, Hassan. "Al-Qaeda Increasingly Reliant on Media." New York Times (2006).

FFI Explains al-Qaida Document. Norwegian Defense Research Establishment, 2004.

Gendron, Angela. Trends in Terrorism Series: Al-Qaeda: Propaganda and Media Strategy. ITAC Presents, 2007.

Geyer, Georg. "Zündschnur der Asymmetrie: Grundsätzliche Überlegungen zum Verhältnis von Politik, Massenkommunikation und Gesellschaft in asymmetrischen Konflikten." In Asymmetrische Kriegführung - ein neues Phänomen der Internationalen 
Politik (Asymmetric Warfare, a New Phenomenon of International Policy), 283-98. Baden-Baden: Nomos, 2004.

Gladwell, Malcolm. The Tipping Point: How Little Things Can Make a Big Difference. New York: Back Bay Books, 2006.

Golan, Guy. "Inter-Media Agenda Setting and Global News Coverage." Journalism Studies 7, no. 2 (2006): 323-33.

Katz, Elihu, and Tamar Liebes. "'No More Peace!' How Disaster, Terror and War Have Up-staged Media Events." International Journal of Communication 1 (2007): 157-66.

Kellner, Douglas. "War Correspondents, the Military, and Propaganda: Some Critical Reflections." International Journal of Communication 2 (2008): 297-330.

König, Ernst. "Österreich - ein Beispiel? (Austria - an Example?)." In Asymmetrische Kriegführung - ein neues Phänomen der Internationalen Politik (Asymmetric Warfare, a New Phenomenon of International Policy), 133-44. Baden-Baden: Nomos, 2004.

Krämer, Benjamin. "The Economy of Media Events: Theory and Examples." International Journal of Communication 2 (2008): 909-24.

Leptien, Frank. "Terrorismus für die Medien? Terrorismus durch die Medien? (Terrorism for the Media? Terrorism by the Media?)." Risser Einblicke 10/11 (2002).

Mehsud, Hakeem Ullah. Taliban Vows to Take over Pakistan. ZeeNews.com, 2008.

Mumbai Rocked by Deadly Attacks. BBC News Online, 2008.

Münkler, Herfried. Der Wandel des Krieges: Von der Symmetrie zur Asymmetrie (The Change of War: From Symmetry to Asymmetry). Weilerswist: Velbrück, 2006.

Salem, Arab, Edna Reid, and Hsinchun Chen. "Content Analysis of Jihadi Extremist Groups' Videos." In Terrorism Informatics: Knowledge Management and Data Mining for Homeland Security, 267-284. New York: Springer, 2008.

Sardar, Ziauddin. "Pakistan: The Taliban Takeover." New Statesman (2007).

Smith, James M., and Brent J. Talbot. "Terrorism and Deterrence by Denial." In Terrorism and Homeland Security - Thinking Strategically about Policy. London: CRC Press, 2008.

Stern, Jessica. "The Protean Enemy." Foreign Affairs 82, no. 4 (2003).

Storsul, Tanja, and Anders Fagerjord. "Digitization and Media Convergence." In The International Encyclopedia of Communication, 1319-1323. Vol. IV. Oxford: Blackwell, 2008.

Stuart, Allan, and Barbie Zelizer. Reporting War: Journalism in Wartime. New York: Routlege, 2004.

Taliban Pledges to Cut NATO Supply Route, Make 2009 a 'Bloody' Year for U.S. Forces. CBS News Investigates, 2009. 
Tatham, Steve. Strategic Communication: A Primer In Advanced Research and Assessment Group. British Defence Academy, 2008.

The Media Activities of the Taliban Islamic Movement. Al-Samood Magazine (2008).

Thomas, Timothy L.. Cyber Silhouettes: Shadows over the Information Operations. Fort Leavenworth: KS: Foreign Military Studies Office, 2005.

von Clausewitz, Carl. Vom Kriege (On War). Troisdorf: Bildungsverlag Eins, 2003.

Warden Message: Powerful Bombing at Islamabad Marriott in Pakistan In Consular Affairs Bulletins . Overseas Security Advisory Council, 2008.

Weimann, Gabriel. www.terror.net - How Modern Terrorism Uses the Internet In Special Report. Washington, D.C.: United States Institute for Peace, 2004.

Whitlock, Craig. "Keeping al-Qaeda in His Grip, Al-Zawahiri Presses Ideology, Deepens Rifts among Islamic Radicals." Washington Post (2006).

Wojcieszak, Magdalena. "Al Jazeera: A Challenge to the Traditional Framing Research." International Communication Gazette 69 (2007): 115-28.

Zarqawi Interview Part Two: Dialogue with Sheikh Abu Musab Al-Zarqawi. Jihad Unspun (2007). 